\title{
Successful Partnerships in Emerging Markets: The Moderating Role of Operational Performance
}

\author{
Felix Nana Abaka Sackey ${ }^{1}$, Livingstone Divine Caesar ${ }^{2, *}$ \\ ${ }^{1}$ Ibistek Ghana Ltd., 29 Josef Broz Tito Ave. Cantonments, Accra, Ghana \\ ${ }^{2}$ CSIR-STEPRI, P. O. Box CT. 519 Cantonments, Accra, Ghana
}

Received February 9, 2021; Revised March 13, 2021; Accepted May 16, 2021

\begin{abstract}
Cite This Paper in the following Citation Styles
(a): [1] Felix Nana Abaka Sackey, Livingstone Divine Caesar, "Successful Partnerships in Emerging Markets: The Moderating Role of Operational Performance," Universal Journal of Management, Vol. 9, No. 3, pp. 83 - 100, 2021. DOI: 10.13189/ujm.2021.090302.
\end{abstract}

(b): Felix Nana Abaka Sackey, Livingstone Divine Caesar (2021). Successful Partnerships in Emerging Markets: The Moderating Role of Operational Performance. Universal Journal of Management, 9(3), 83 - 100. DOI: 10.13189/ujm.2021.090302.

Copyright $\odot 2021$ by authors, all rights reserved. Authors agree that this article remains permanently open access under the terms of the Creative Commons Attribution License 4.0 International License

\begin{abstract}
Purpose - With the reported high failure rate among Small and Medium-sized Enterprises (SMEs) in the professional service sector of emerging markets, coalescing their resources via strategic partnerships to effectively compete in the market place is seen as crucial to their growth and survival. This paper investigates the impact of attributes of partnership, communication behaviour and collaborative conflict resolution on partnership success among Professional Service Firms (PSFs) in emerging markets. It further contributes to the body of knowledge by exploring the moderating role of operational performance in the hypothesised relationships. Design/methodology/approach - Relying on a positivistic paradigm, 300 small and medium-sized PSFs were surveyed, yielding a $79 \%$ response rate. Descriptive statistics, hierarchical regression and exploratory factor analysis were used to analyse the collected data. Findings - A positive significant relationship was found between two of the three dimensions of attributes of partnership (commitment and coordination) and the success of partnerships. Despite their importance for partnerships, trust and information sharing negatively impacted partnership success in this study. A positive significant impact was however realised for trust and information sharing when operational performance moderated the relationship. Practical implications - PSFs must develop innovative and workable tools to effectively monitor their operational performance given its significant influence on the relationship between attributes of
\end{abstract}

partnership, communication behaviour and partnership success. Social and cultural competence training is needed for staff to improve the relationship bond, trust and collective goals of partnerships. Originality/value - This paper introduces operational performance as a moderating variable to investigate the hypothesised relationships. It offers insights into how PSFs can manage the pertinent issues critical to the effective management of partnerships in emerging markets.

Keywords Partnership, Professional Service Firms, Operational Performance, Partnership Success, Critical Success Factors, SMEs

\section{Introduction}

Characteristically, professional service firms (PSFs) occupy a strategic position within the economies of emerging markets; mostly operating as SMEs. With increased competition emanating from both the global and local business environments, PSFs must refocus their strategies to remain competitive and sustainable [1,2]. Although a strategic partnership is proposed as one of the key survival strategies [2], little is known concerning the dynamics of building successful partnerships among small medium-sized firms in developing markets such as Ghana. Also, further research is needed to gain a better 
understanding of how to promote partnership success among PSFs and other SMEs due to the following reasons:

- Structural differences in ownership, philosophies and modus operandi of firms [3,4].

- High partnership failure rates in emerging markets $[1,3$,$] .$

- Volatile and unpredictable features that are unique to emerging markets

To address the high failure rate characteristic of partnerships in emerging markets [3], a nuanced understanding of the reasons for partnership formation, obstacles and critical success factors is imperative. Aside from the economic reasons which are embedded in the cost and information sharing opportunities, firms enter into partnerships to exploit the inherent benefits of the ensuing synergistic capabilities (e.g. increased access to human and capital resources to effectively compete) [2]. However, an ill-managed partnership is bound to fail regardless of the reason for its formation. Despite this understanding, there is limited research that investigates the mechanics of effective partnership practice among SMEs (and specifically PSFs) from an emerging market perspective. Such knowledge is needed if partnerships are to remain profitable and sustainable [4].

The professional service industry in emerging market such as Ghana is characterized by small and medium-sized PSFs who have limited access to finance. Also, these PSFs are saddled with limited managerial capabilities and regulatory constraints; further undermining their ability to internationalize and compete in global markets. Despite the capacity of partnerships to address these limitations, most PSFs remain small, operate independently and reluctant to ally with other firms. It is important to unravel the reasons for this negative syndrome. Thus, this paper investigates how factors such as partnership attributes, communication behaviour and effective collaborative conflict resolution among partners might lead to partnership success. Although these direct hypothesised relationships were already explored in previous studies [4,5], the current paper has become necessary and adds value in the following manner:

- Previous studies investigating the direct relationships are between 2-3 decades old [4,5,13]. Over time, new changes emerged in the business environment suggesting the possibility of fresh insights from a more current study.

- Also, past studies only focused on developed economies, leading to the structural exclusion of emerging markets which possess different characteristics (volatility, uncertainty, ambiguity, etc.). This paper may help provide any divergent/contradictory findings that previous studies consequently missed out on. The potentially different evidence could provide a blueprint for the practice of effective partnership among PSFs and other SMEs in emerging markets.
Moreover, this paper improves upon the conceptual model used in prior studies by introducing a moderator variable - operational performance. This adds to existing knowledge as the direct relationship explored by previous studies [4,5] lacks sophistication. With the introduction of operational performance as a moderator variable, this paper thus presents a sophisticated appreciation of the relationship between the critical success factors of partnership and partnership success.

Thus, this paper introduces partners' economic and operational performances as the conditions that might either enhance or decrease the effects of the critical success factors of partnership on partnership success. Theoretically, the study introduces social exchange and transaction cost theories to explain the workings and dynamics of partnership among small firms in developing economies.

\section{Literature Review}

\section{Professional service firms (PSFs)}

As firms operating in the knowledge-based sector of the economy, PSFs are noted for their mastery of particular expertise [6]; and operate with low capital intensity. Past frameworks developed on professional businesses have often been limited to expert knowledge application and manufacturing firms; lacking systematic inter-profession comparisons. Most of these studies dwelt on a single professional sector, such as law, accounting, engineering consulting, architecture, or management consulting. In studying PSFs in three different sectors (i.e. accounting law and engineering consultancy), Mohr and Spekman [5] highlighted their heterogeneity based on "the nature of the knowledge they deploy, contests occurring around rival jurisdictional claims and the nature of the relationship with other actors including the state and clients".

To effectively manage PSFs, a high degree of skill and dexterity is needed to help with accurate troubleshooting of client's problems and proffering workable solutions. The multiplicity of technical insight needed in recent time to manage PSFs, adequately address client needs and sustainably compete in an increasingly dynamic marketplace is unconsciously making a strong case for the need to engage in strategic partnerships. Such partnerships will typically involve a long-term relationship between two or more firms working towards a common goal and to achieve greater benefits by operating jointly rather than in isolation. [7]. Effective management of PSFs also hinges on addressing the emerging challenges confronting them to avoid their exposure to the risk of folding up. Thus, the overarching goal is to promote the long-term sustainability of the firm and even increase its size.

\section{Theoretical framework and conceptual model}

The paper uses the social exchange and the transaction cost theories to demonstrate the mechanics by which 
critical success factors (i.e. attributes of partnership, communication behaviour and collaborative conflict resolution) lead to partnership success. Social exchange theory [8] espouses a relationship between at least two partners aimed at the achievement of some benefits. The parties make either tangible or intangible sacrifices (cost) in anticipation of the positive outcome of the relationship. The parties are thus motivated by the expected returns. It is thus a reciprocating relationship of some sort. Similar to social exchange relationships, partnerships are associated with certain behavioural traits that distinguish them from conventional organisational alliances. Consequently, when firms display particular traits in their partnerships, the relation is more likely to succeed and vice versa. For instance, attributes of partnership and communication behaviours such as information sharing, commitment and trust are connected to partnership success as such behaviours create a positive impact [9].

Deployed as a supplementary theory in this study, the transaction cost theory sheds light on the strategic alliance (partnership) relationship between firms by highlighting the fact that economic motives primarily underpin the formation of such alliances among firms. The transaction cost theory is usually used to explain the motive behind why a firm or an individual will go into some sort of partnership with another firm or individual. The conceptual model of the study showing the independent, dependent and moderating variable is shown in Figure 1.

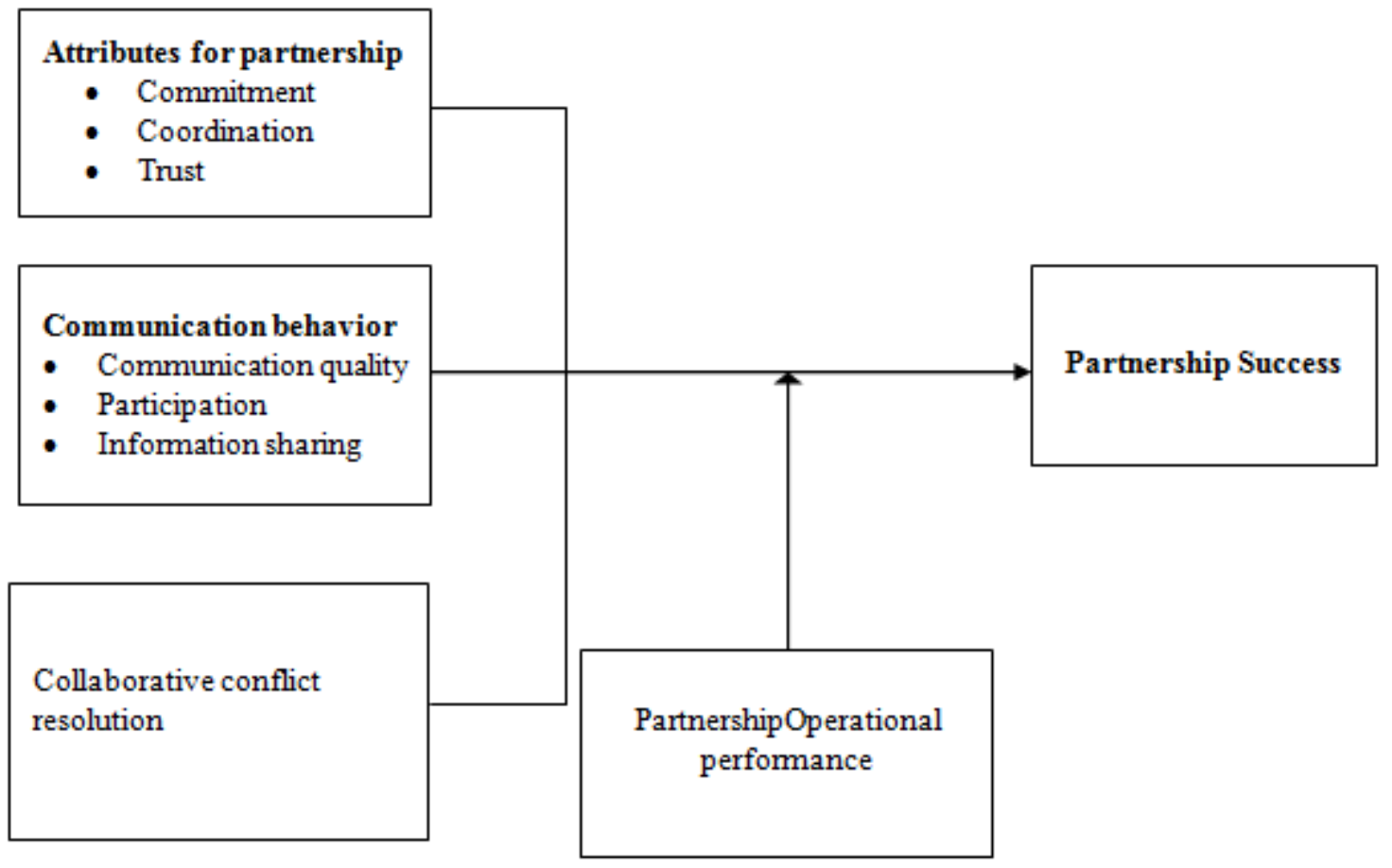

Figure 1. Conceptual model 


\section{Development and presentation of hypotheses}

Attributes for partnerships

The attributes for partnership concern a bouquet of dimensions (constructs) connected to the management of interactions among members of a partnership alliance. These attributes also relate to the collection of factors important to effective coordination of the multiplicity of issues underpinning modern-day partnerships. Although these attributes are many, the extant literature predominantly focuses on interdependence, commitment, coordination, trust etc. [5]. To a large extent, the success of partnerships is believed to hinge on a combination of these attributes.

\section{Commitment}

Commitment describes the readiness of partners to sacrifice and make the needed inputs towards a successful partnership alliance [5]. It naturally follows that a high level of commitment is a necessity for partners who desire to work out a relationship that positions them to sustainably compete in the market place. There is consensus in the literature that a higher level of commitment helps in the achievement of partnership goals thus culminating in partnership success [5,10]. Measuring partnership success using the satisfaction of partners, Mohr and Spekman [5] found that commitment positively impacted on the satisfaction of partner contributions and profits. This suggests a positive relationship between commitment and partnership success. It is thus hypothesised that;

H1: Commitment of partners has a positive relationship with partnership success

\section{Coordination}

Strategic alliances (partnerships) are more likely to be successful when partners effectively perform the collection of tasks placed on them by either side of the relationship $[10,11]$. With greater coordination, partners develop agility and reflex capabilities to address emerging issues that may threaten their growth and survival promptly. This ultimately saves the partnership from collapsing and eventually produces success. Mohr and Spekman [5] found that coordination as a dimension of partnership success impacted positively on the satisfaction of partners (which was used as a dependent variable in that study). It is thus hypothesised that:

H2: Coordination has a positive relationship with partnership success

\section{Trust}

Trust is essentially the belief that a party's word is reliable and that they will redeem a promise made through a specific set of actions. It is construed as the foundation of any successful partnership given its ability to promote transparency and intensify collaborative efforts among partners through information exchange [2]. Consequently, the lack of trust in partnerships undermines information exchange between partners and collective troubleshooting of emerging problems. Unfavourable partnership outcomes are likely to ensue in partnerships suffering from lack of trust as suspicion of the actions of relationship partners become rife. Trust related factors were found to positively impact partnership success [5]. It is thus hypothesised that;

H3: Trust among partners has a positive relationship with partnership success

\section{Communication behaviour}

Aside from the attributes of partnerships, communication behaviour also stands out as one of the key antecedents of partnership success [2,12]. Communication is instrumental to the success of most strategic partnerships given its influence on information exchange and collaboration among firms [2,9]. The paper discusses three dimensions of the communication behaviour construct (i.e. communication quality, degree of information sharing between partners, and participation in planning and goal setting).

\section{Communication quality}

During the transmission of information, communication quality is critical as this entails the accuracy, timeliness, adequacy, and credibility of the exchanged information. Communication quality impacts the success of organisations [13]. Thus, partnerships are bound to be successful where the parties work to improve the aforementioned aspects of communication quality. Timely, accurate, and relevant information is essential if the goals of the partnership are to be achieved. Timely communication to supply chain partners, for instance, adds distinctive value which positively impacts the bottom-line of firms. On the flip side, poor quality of communication contributes to the failure of partnerships. It is thus hypothesised that:

H4: Communication quality has a positive relationship with partnership success

\section{Participation}

As one of the key dimensions of communication behaviour, participation means strategic partners must collectively plan, set and execute goals that will enhance their capacity to sustainably compete in the marketplace $[10,14]$. Sharing roles and responsibilities is the overriding feature of participation in partnerships. Given the nexus between participatory decision-making and partner satisfaction, emphasis must be placed on activities (decision making, communication, planning, etc) that promote higher participation among partners [5]. Increased participation in the aforementioned critical partnership activities will lead to partnership success [10]. It is thus hypothesised that:

H5: Participation has a positive relationship with partnership success 


\section{Information sharing}

Information sharing is critical to the growth and survival of strategic partnerships $[5,15]$. In strategic supply chain partnerships, for instance, the sharing of quality information among members has a significant positive influence on the goals, expectations and outcomes [16]. When quality information is shared in an efficient and timely manner, it enables members of a partnership to improve their agility and other capabilities needed to sustainably compete in both the local and global markets [17]. Further, information sharing helps to improve the relationship among partners, improve the quality of decision making which ultimately impacts on the performance of the organisations involved in the partnership. It is consequently hypothesised that:

H6: Effective information sharing has a positive relationship with partnership success

Conflict resolution techniques

Naturally, conflicts form part of most strategic partnerships. This is mostly attributable to the differences in the ideologies and structural formation of firms [18]. Consequently, parties to inter-organisational partnerships must develop a thorough mind map of the potential conflict areas and steer clear them to maintain their relationship $[19,20]$. Partnerships that adopt joint developmental rather than judgmental conflict resolution approaches are very much likely to succeed. The use of persuasive and constructive confliction resolution options will produce more productive partnerships in the long run and vice versa $[5,20]$. It is thus hypothesised that:

H7: The application of effective conflict resolution techniques has a positive relationship with partnership success

\section{The Moderating role of operational performance}

In partnerships, operational performance is described as the presence of effective work, resources, and risk-sharing and astute responsiveness among partners [2]. When partners effectively combine the aforementioned factors to work towards the achievement of their common goal, it is likely to result in favourable outcomes [5].

The influence of partnership operational performance is used in this study to moderate the influence of factors like attributes for partnership, communication behaviour and collaborative conflict resolution on the level of partnership success in an institution. Partnership's operational performance helps firms to reduce the cost of operating alone and appropriately respond to market failures from risk-sharing to increase output [5]. There is a positive relationship between certain dimensions of attributes of a partnership (i.e. commitment) and partnership success. When people are completely committed to maintaining their business relationship as partners, it propels them to put their all on the line to improve perception about their brand for the fulfillment of the strategic goals. From the argument above, the researchers hypothesise that:

H8: The positive relationship between commitment and partnership success will be stronger when the operational performance of the partnership is high than low

An organization that relies on standard operating procedures like rules, policies, and forms created by partner organizations to coordinate each other's activity in their collaboration coupled with partnership agreements to increase their output contributes to partnership success of firms partners $[3,5,15]$. Regular participation of firm's top executives on the boards or steering committee specifically created for making decisions about the collaboration of partnership in addition to their partnership drive to spread their risks of operation can influence effective partnerships. It is thus hypothesised that:

H9: The positive relationship between coordination and partnership success will be stronger when the operational performance of the partnership is high than low

In considering the influence partnership operational performance has on the relationship between trust and partnership success. When business partners have hidden agendas and bring these into the partnership, it is likely to undermine the drive towards growth and survival for the partnership. Business partners that can be relied upon to do what they say they will do for the partnership arrangements to spread their risks of operating influences partnership success. From the above argument, it is hypothesised that:

H10: The positive relationship between trust among partners and partnership success will be stronger when the operational performance of the partnership is high than low

Partners engaged with one another in completely, honest, open and timely communication create value that leads to effective partnership relationships $[12,15,16]$. Business partners that regularly ask for advice in addition to the objective of getting and understudying new competitors can contribute more to value addition to their firms relative to firms that do not have quality communication structures in place $[5,6]$. The ability of partners to communicate their changing demands regarding the partnerships and stakes in achieving an increase in their revenue proceeds often realize partnership successes than firms that do not. When partners always confer on the planning of activities as well as their thought about ways of creating entry barriers in their area of practice will influences partnership success. It is thus hypothesised that:

H11: The positive relationship between communication quality among partners and partnership success will be stronger when the operational performance of the partnership is high than low

When making decisions in partnerships, it is expected that partners seek the input of all the stakeholders as the multiplicity of viewpoints could be a strategic source of complementary skills and capabilities for effective 
outcomes. Firms that participate in goal setting and forecasting with their business partners to increase marketing economies of scale can contribute to partnerships with added value for the business [5]. Business partners that help others with their planning activities coupled with their partnership to spread their risks of operating influences the effectiveness of their organization through effective partnerships. Effective participation means that a culture of candour must be encouraged to breed knowledge sharing among partners [2]. It is thus hypothesised that:

H12: The positive relationship between partner participation and partnership success will be stronger when the operational performance of the partnership is high than low

Effective sharing of business information within partnerships leads to the effectiveness of the relationship [11-14] when people inform their business partners in advance of changing needs and preferences, and other relevant details crucial to the growth of their partnership, it results in value addition. In a firm's business relationships, accessing helpful information in addition to shared partnership goal to increase collective output influences the success of partnerships among key stakeholders [5-8]. Thus, the profitability of firms is seen to increase from partnership successes when parties keep each other informed about events or changes that may affect their ability to respond to market changes. Information sharing should thus be given priority in either face-to-face or online interactions as it leads to shareholder value creation and also influences the quality of operations [5]. Over time, the sharing of information leads to a reduction in costs and an increase in revenues recorded by firms. It is thus hypothesised that:

H13: The positive relationship between effective information sharing among partners and partnership success will be stronger when the operational performance of the partnership is high than low

In considering the influence partnership operational performance has on the relationship between collaborative conflict resolution and partnership success a study posits that business that can think of several ways of dealing with disagreement, also, to focus on increasing their output influences the effectiveness of partnerships in their organization [5]. Collaborative conflict resolution in the form of businesses thinking of how to respond to conflict coupled with their shared focus on increasing their technical economies of scale has positive implications for the profitability of the firm in the short to long term [1-4].

The way organizations resolve conflicts usually strengthen their relationship with their partners. This coupled with shared acquired additional resources lead to an effective partnership among shareholders. It is thus hypothesised that:

H14: The positive relationship between the application of effective conflict resolution among partners and partnership success will be stronger when the operational performance of the partnership is high than low

\section{Procedures and Methods}

The quality of any given research hinges on choosing an appropriate paradigmatic and methodological position and making sampling decisions guided by scientifically grounded tenants of inquiry [21,22]. Consequently, this paper holds an objective ontological stance, thus, the researchers are of the view that the critical success factors that impact on partnership success exist and are external to the researchers. Given that the objective of the paper is to identify the factors critical to the success of partnerships, the positivistic paradigm was adopted. This enabled the use of a quantitative research approach. The positivistic paradigm assumes an objective, quantitative approach, where it uses a hypothetic-deductive technique beginning with problem definition, development of hypotheses, data collection and analysis including interpretation of data [21]. For the current study, using the hypothetic-deductive technique helped to explain the predicted causal relationships between the critical success factors of partnership and partnership success.

Power analysis of a chi-square test was conducted in G-POWER to determine a sufficient sample size using an alpha of 0.05 , the power of 0.95 , a medium effect size $(\mathrm{w}=$ 0.15) (Faul et al., 2013). Based on the aforementioned assumptions, the desired sample size was 154 . However, the sample size for the study was increased and a total of three hundred and fifty (350) survey respondents were targeted for this study to ensure proper representativeness of the study population. The questionnaire designed for this study was sent and distributed to participants through field interviewers and collected after completion. To ensure the quality of the information collected, a back check of the responses was made. Respondents were called to verify fifty percent of the information provided as part of the quality assurance process.

The study questionnaire was developed with multi-item measures based on construct definitions and research precedents. A pretest of the study was conducted 50 accountants as they share attributes similarity to that of the PSFs. Some minor changes were made to the wording in the questionnaire based on the feedback from the pretest. The design of the data collection instrument was greatly influenced by the study questions, hypotheses and conceptual model. The questionnaire was divided into two parts, namely Part I: consisting of the 5 sectioned Likert Scale questions (A-E). Part II the Bio-Data and comprised demographic questions. Most measures in the questionnaire were chosen from those that had been employed in previous research. If the variables had satisfying quality in previous literature variables, they were 
adopted. Further, some measures were adopted.

The construct commitment was measured using six items which were adapted from Rusbult et al., [23]. The measures for coordination were adapted from the one used by Thomson, Perry, and Miller [25]. It used six items. Using Jones and Barry [24], trust was measured using six scale items. The five scale items used in measuring communication quality was culled from de Waal, Goedegebuure and Hinfelaar [26]. The initial five items and six items were respectively used to measure participation and information sharing adapted from the one used by Mohr and Spekman [5]. The operational performance construct was measured using a 15-item questionnaire adapted from Brouthers, Van Rustenburg and Van Den Ven [27]. Finally, the initial nine items that were used to measure collaborative conflict resolution was adapted from the one used by Gaumer, Soukup, Noonan, and McGurn [28].

Ethical considerations in data collection were highly considered and maintained by this study. Ethical issues are important throughout the research process to establish the ethical integrity of the research and the researcher. Issues connected to confidentiality, securing the informed consent of study participants and anonymity were addressed. To maintain the confidentiality of the sample population, for instance, each organization and its employees sampled were assigned a unique code to prevent them from being traced to their respective responses [21]. Thus, the use of codes was useful in making the contributions of respondents confidential and non-attributable. Respondents' biographical data was strictly kept anonymous.

\section{Results and Findings}

\section{Background information of respondents}

In total, 276 responses representing a $79 \%$ response rate was received from the data collection exercise. Table 1 and 2 respectively present the demographic characteristics of the respondents and their organisations.

There were more males $(94.1 \%)$ than females $(5.9 \%)$ suggesting that PSFs have more male workers. Also, more than $80.9 \%$ of respondents were over 41 years with half (49.1\%) occupying manager positions. Most partnerships often appoint a person as a manager to manage the operations of the alliance. In total, $45.8 \%$ of participants had over 10 years working experience in their firms, with $46.9 \%$ having their bachelors and $27.1 \%$ having a professional qualification such ACCA. The high education level evident among respondents reflects the knowledge-intensive nature of the professional service sector.

Table 1. Demographic characteristics of respondents

\begin{tabular}{|c|c|c|c|}
\hline Variable & Characteristics & Frequency & Percent \\
\hline \multirow[t]{2}{*}{ Gender } & Male & 257 & $94.1 \%$ \\
\hline & Female & 16 & $5.9 \%$ \\
\hline \multirow[t]{5}{*}{ Age } & Below 20years & 1 & $.4 \%$ \\
\hline & 26-30years & 3 & $1.1 \%$ \\
\hline & 31-35years & 20 & $7.3 \%$ \\
\hline & $36-40$ years & 29 & $10.6 \%$ \\
\hline & $\begin{array}{c}41 \text { and above } \\
\text { years }\end{array}$ & 220 & $80.6 \%$ \\
\hline \multirow[t]{3}{*}{ Position } & $\begin{array}{c}\text { Chief Executive } \\
\text { Officers }\end{array}$ & 85 & $31.1 \%$ \\
\hline & Manager & 134 & $49.1 \%$ \\
\hline & $\begin{array}{l}\text { Administrative } \\
\text { officer }\end{array}$ & 41 & $15.0 \%$ \\
\hline \multirow[t]{5}{*}{$\begin{array}{l}\text { Experience in } \\
\text { organization }\end{array}$} & Below 1 year & 1 & $.4 \%$ \\
\hline & $1-3$ years & 30 & $11.0 \%$ \\
\hline & 4-7 years & 100 & $36.6 \%$ \\
\hline & $8-10$ years & 17 & $6.2 \%$ \\
\hline & Above 10 years & 125 & $45.8 \%$ \\
\hline \multirow[t]{5}{*}{ Education } & $\mathrm{PhD}$ & 2 & $.7 \%$ \\
\hline & Masters & 67 & $24.5 \%$ \\
\hline & Bachelors & 128 & $46.9 \%$ \\
\hline & Diploma & 2 & $.7 \%$ \\
\hline & $\begin{array}{c}\text { Professional } \\
\text { Qualification } \\
\text { (ACCA, CA } \\
\text { Ghana etc.) }\end{array}$ & 74 & $27.1 \%$ \\
\hline
\end{tabular}

Note: The population $(\mathrm{N})$ differ across variables due to missing values

Table 2 shows that $90.5 \%$ of the surveyed firms had employee size less than 20; confirming that SMEs mostly have less than 20 employees. About $50.5 \%$ of respondents worked for organisations that were in existence for 11-15 years. 
Table 2. Background information of the organization

\begin{tabular}{|c|c|c|c|}
\hline Variable & Characteristics & Frequency & Percent \\
\hline \multirow[t]{3}{*}{ Employee size } & Less than 20 & 247 & $90.5 \%$ \\
\hline & $21-50$ & 25 & $9.2 \%$ \\
\hline & $50-99$ & 1 & $.4 \%$ \\
\hline \multirow[t]{5}{*}{$\begin{array}{l}\text { Company } \\
\text { existence }\end{array}$} & $0-5$ years & 16 & $5.9 \%$ \\
\hline & $6-10$ years & 44 & $16.1 \%$ \\
\hline & $11-15$ years & 138 & $50.5 \%$ \\
\hline & $16-20$ years & 65 & $23.8 \%$ \\
\hline & 21 years and above & 10 & $3.7 \%$ \\
\hline \multirow{3}{*}{$\begin{array}{l}\text { Partnership } \\
\text { type }\end{array}$} & Acquisition & 28 & $10.3 \%$ \\
\hline & Strategic Alliance & 1 & $.4 \%$ \\
\hline & General Practice & 244 & $89.4 \%$ \\
\hline \multirow[t]{3}{*}{$\begin{array}{l}\text { Number of } \\
\text { partners }\end{array}$} & 1 partner & 86 & $31.5 \%$ \\
\hline & 2 partners & 177 & $64.8 \%$ \\
\hline & 3 partners & 10 & $3.7 \%$ \\
\hline \multirow[t]{5}{*}{$\begin{array}{l}\text { Partnership } \\
\text { age }\end{array}$} & Below 1 year & 4 & $1.5 \%$ \\
\hline & 2 years & 223 & $81.7 \%$ \\
\hline & 3 years & 30 & $11.0 \%$ \\
\hline & 4 years & 5 & $1.8 \%$ \\
\hline & 5 years and above & 11 & $4.0 \%$ \\
\hline \multirow[t]{3}{*}{$\begin{array}{l}\text { Average } \\
\text { revenue }\end{array}$} & $\begin{array}{c}\text { Gh } \varnothing \text { less than } 5 \\
\text { million }\end{array}$ & 251 & $92.3 \%$ \\
\hline & Gh $\varnothing$ 6-10 million & 19 & $7.0 \%$ \\
\hline & Gh $\varnothing 21-25$ million & 2 & $.7 \%$ \\
\hline
\end{tabular}

Note: The population $(\mathrm{N})$ differ across variables due to missing values

\section{Measures and validation}

Table 3 shows the factor loadings and Cronbach values of the constructs (variables) shown in Figure 1. Cronbach [29] minimum Alpha value of 0.60 was adopted and attests to reliability and sufficiency of all the scales used as the minimum value was exceeded. The internal validity and consistency of the scale items used to measure the variables are also shown. The exploratory factor analysis (EFA) used the Principal Component Analysis (PCA) factoring method and varimax rotation that the minimum value was exceeded. The average variance extracted (AVE) (Fornell \& Larcker, 1981) loadings for the measures of each construct were all relatively large and positive above .50 . Table 3 also shows the sources of the scale items of the constructs.

\section{Correlation and descriptive}

Correlation among the constructs and the descriptive statistics as shown in Table 4 denotes an absence of multicollinearity. Collaborative conflict resolution $(r(276)$ $=.703, p<.01)$ positively correlated successful partnership, just as the case for information sharing $(r(276)=.024$, $p>.01) ;$ participation $(r(276)=.487, \quad p<.01)$; communication quality $(r(276)=.511, p<.01)$; coordination $(r(276)=.288, p<.01)$; and commitment $(r(276)=.115, p<.01)$. However, trust $(r(276)=-.052$, $p>.01)$ negatively correlated successful partnership.

The data was normally distributed since the skewness and kurtosis were approximately between -1 and +1 . Respondents generally showed agreement to commitment (Mean $=4.70, S D=.33)$, information sharing $($ Mean $=4.21$, $S D=.46$ ), participation (Mean $=4.16, S D=.39$ ), coordination $($ Mean $=4.14, S D=.65)$, successful partnership (Mean $=4.0, S D=.63)$, collaborative conflict resolution (Mean $=3.95, S D=.54)$ and communication quality (Mean $=3.86, S D=.55$ ). as associated with establishing a successful partnership. The respondents however expressed disagreement with respect trust (Mean $=2.99, S D=1.28$ ) issues when dealing with partners. 
Table 3. Measurement summary

\begin{tabular}{|c|c|c|c|c|c|}
\hline Source & Construct & Items & Loadings & $\alpha$ & AVE \\
\hline \multirow{5}{*}{$\begin{array}{c}\text { Adapted from } \\
\text { Rusbult et al. [23] }\end{array}$} & & & & .700 & 0.50 \\
\hline & Commitment & $\begin{array}{l}\text { 1. I feel awful when our strategic plans towards the } \\
\text { growth of the partnership go bad }\end{array}$ & .806 & & \\
\hline & & $\begin{array}{l}\text { 2. I am completely committed to maintaining our } \\
\text { business relationship and building more } \\
\text { relationships with other partners }\end{array}$ & .699 & & \\
\hline & & $\begin{array}{l}\text { 3. I will do everything I can to make our partnership } \\
\text { grow }\end{array}$ & .666 & & \\
\hline & & $\begin{array}{l}\text { 4. I spend a lot of time thinking about the future of } \\
\text { our business partnership }\end{array}$ & .615 & & \\
\hline \multirow{7}{*}{$\begin{array}{l}\text { Adapted from } \\
\text { Thomson, Perry } \\
\text { and Miller [25] }\end{array}$} & & & & .847 & 0.65 \\
\hline & Coordination & $\begin{array}{l}\text { 1. I participate on a board or steering committee } \\
\text { specifically created for making decisions about } \\
\text { the collaboration of partnership }\end{array}$ & .875 & & \\
\hline & & $\begin{array}{l}\text { 2. All partners have to agree before a decision is } \\
\text { made about the goals and activities of the } \\
\text { collaboration }\end{array}$ & .870 & & \\
\hline & & $\begin{array}{l}\text { 3. Partners formally evaluate the success of the } \\
\text { collaboration }\end{array}$ & .838 & & \\
\hline & & $\begin{array}{l}\text { 4. My organization relies on a formal agreement that } \\
\text { spells out relationships between partners }\end{array}$ & .747 & & \\
\hline & & $\begin{array}{l}\text { 5. I know what resources (like money, time, } \\
\text { expertise) the partner brings to the partnership }\end{array}$ & .676 & & \\
\hline & & & & .922 & 0.87 \\
\hline \multirow{3}{*}{$\begin{array}{c}\text { Adapted from } \\
\text { Jones and Barry } \\
{[24]}\end{array}$} & Trust & $\begin{array}{l}\text { 1. The contributions of all partners are valued } \\
\text { equally, irrespective of whether a majority agree } \\
\text { or disagree with their point of view }\end{array}$ & .950 & & \\
\hline & & $\begin{array}{l}\text { 2. Business partners have hidden agendas and bring } \\
\text { these into the partnership }\end{array}$ & .948 & & \\
\hline & & $\begin{array}{l}\text { 3. Partners withhold information of relevance to the } \\
\text { partnership }\end{array}$ & .895 & & \\
\hline \multirow{5}{*}{$\begin{array}{l}\text { Adapted from de } \\
\text { Waal et al. [26] }\end{array}$} & & & & .539 & 0.50 \\
\hline & $\begin{array}{l}\text { Communication } \\
\text { quality }\end{array}$ & $\begin{array}{l}\text { My partner communicates his changing demands } \\
\text { regarding the partnership in time to me }\end{array}$ & .816 & & \\
\hline & & $\begin{array}{l}\text { 2. My partner keeps me well (completely, honestly, } \\
\text { openly, timely) informed on developments }\end{array}$ & 752 & & \\
\hline & & $\begin{array}{l}\text { My partner and I always confer on the planning of } \\
\text { activities }\end{array}$ & .533 & & \\
\hline & & My partner regularly asks me for advice & .519 & & \\
\hline
\end{tabular}

All items were measured on five-point scales anchored by "strongly disagree" and "strongly agree".

$\mathrm{AVE}=$ Average Variance Explained 
Table 3 Contd. Measurement summary

\begin{tabular}{|c|c|c|c|c|c|}
\hline Source & Construct & Items & Loadings & $\alpha$ & AVE \\
\hline \multirow{5}{*}{$\begin{array}{l}\text { Adapted from Mohr } \\
\text { and Spekman [5] }\end{array}$} & \multirow{5}{*}{ Participation } & & & .572 & 0.50 \\
\hline & & $\begin{array}{l}\text { 1. My advice and counsel are sought by my business } \\
\text { partner }\end{array}$ & .764 & & \\
\hline & & $\begin{array}{l}\text { 2. I participate with goal setting and forecasting with } \\
\text { my business partner }\end{array}$ & .748 & & \\
\hline & & $\begin{array}{l}\text { 3. I help our business partner with their planning } \\
\text { activities }\end{array}$ & .620 & & \\
\hline & & $\begin{array}{l}\text { 4. Suggestions by me are encouraged by my business } \\
\text { partner }\end{array}$ & .552 & & \\
\hline \multirow{5}{*}{$\begin{array}{l}\text { Adapted from Mohr } \\
\text { and Spekman [5] }\end{array}$} & \multirow{5}{*}{ Information sharing } & & & .700 & 0.53 \\
\hline & & $\begin{array}{l}\text { 1. In our business relationship, it is expected that any } \\
\text { information which might help the other party is } \\
\text { provided }\end{array}$ & .852 & & \\
\hline & & $\begin{array}{l}\text { 2. the parties are expected to keep each other } \\
\text { informed about events or changes that may affect } \\
\text { the other }\end{array}$ & .820 & & \\
\hline & & $\begin{array}{l}\text { 3. my partner and I share information through } \\
\text { face-to-face interaction }\end{array}$ & .652 & & \\
\hline & & $\begin{array}{l}\text { 4. I inform my business partner in advance of } \\
\text { changing needs and preferences }\end{array}$ & .532 & & \\
\hline \multirow{6}{*}{$\begin{array}{l}\text { Adapted from } \\
\text { Gaumer et al. [28] }\end{array}$} & \multirow{6}{*}{$\begin{array}{l}\text { Collaborative } \\
\text { conflict resolution }\end{array}$} & & & .755 & 0.55 \\
\hline & & $\begin{array}{l}\text { The way our organization resolves conflict usually } \\
\text { strengthen our relationship with our partners }\end{array}$ & .833 & & \\
\hline & & $\begin{array}{l}\text { We are happy about how our organization handle } \\
\text { most of the disagreement with our partners }\end{array}$ & 822 & & \\
\hline & & $\begin{array}{l}\text { In an argument, we try to understand the point of } \\
\text { view of our business partners }\end{array}$ & .776 & & \\
\hline & & $\begin{array}{l}\text { 4. Our business can think of several ways of dealing } \\
\text { with disagreement }\end{array}$ & .682 & & \\
\hline & & $\begin{array}{l}\text { 5. We try to understand if a disagreement is caused } \\
\text { by misunderstanding }\end{array}$ & .552 & & \\
\hline \multirow{6}{*}{ No source } & \multirow{6}{*}{$\begin{array}{l}\text { Success in } \\
\text { partnership }\end{array}$} & & & .857 & 0.64 \\
\hline & & $\begin{array}{l}\text { I have an effective partnership relationship with } \\
\text { my partner }\end{array}$ & .876 & & \\
\hline & & $\begin{array}{l}\text { The partnership increases the effectiveness of our } \\
\text { organization }\end{array}$ & .865 & & \\
\hline & & $\begin{array}{l}\text { The partnership increases the profitability of our } \\
\text { profit organization }\end{array}$ & .829 & & \\
\hline & & $\begin{array}{l}\text { The partnership increases the quality of our } \\
\text { organization }\end{array}$ & .761 & & \\
\hline & & $\begin{array}{l}\text { The partnership has enhanced my brand } \\
\text { perception }\end{array}$ & .649 & & \\
\hline
\end{tabular}

Note: These items were used for further analysis of the study

All items were measured on five-point scales anchored by "strongly disagree" and "strongly agree".

Table 3 Contd. Measurement summary

\begin{tabular}{|c|c|c|c|c|c|}
\hline Source & Construct & Items & Loadings & $\alpha$ & AVE \\
\hline \multirow{5}{*}{$\begin{array}{c}\text { Adapted from } \\
\text { Mohr and Spekman } \\
\text { [5] }\end{array}$} & \multirow[t]{5}{*}{$\begin{array}{l}\text { Operational } \\
\text { performance }\end{array}$} & $\begin{array}{l}\text { 1. I am in this partnership in a bid to respond to my } \\
\text { market failures }\end{array}$ & .925 & \multirow[t]{5}{*}{.857} & \multirow[t]{5}{*}{0.67} \\
\hline & & $\begin{array}{l}\text { 2. I am in this partnership in a bid to reduce the } \\
\text { cost of operating alone }\end{array}$ & .915 & & \\
\hline & & I am in this partnership to acquire a competitor & .817 & & \\
\hline & & $\begin{array}{l}\text { 4. I am in this partnership to create entry barriers in } \\
\text { my area of practice }\end{array}$ & .774 & & \\
\hline & & $\begin{array}{l}\text { 5. I am in this partnership to spread my risks of } \\
\text { operating }\end{array}$ & .637 & & \\
\hline
\end{tabular}

Note: These items were used for further analysis of the study

All items were measured on five-point scales anchored by "strongly disagree" and "strongly agree".

$\mathrm{AVE}=$ Average Variance Explained 
Table 4. Correlation among constructs

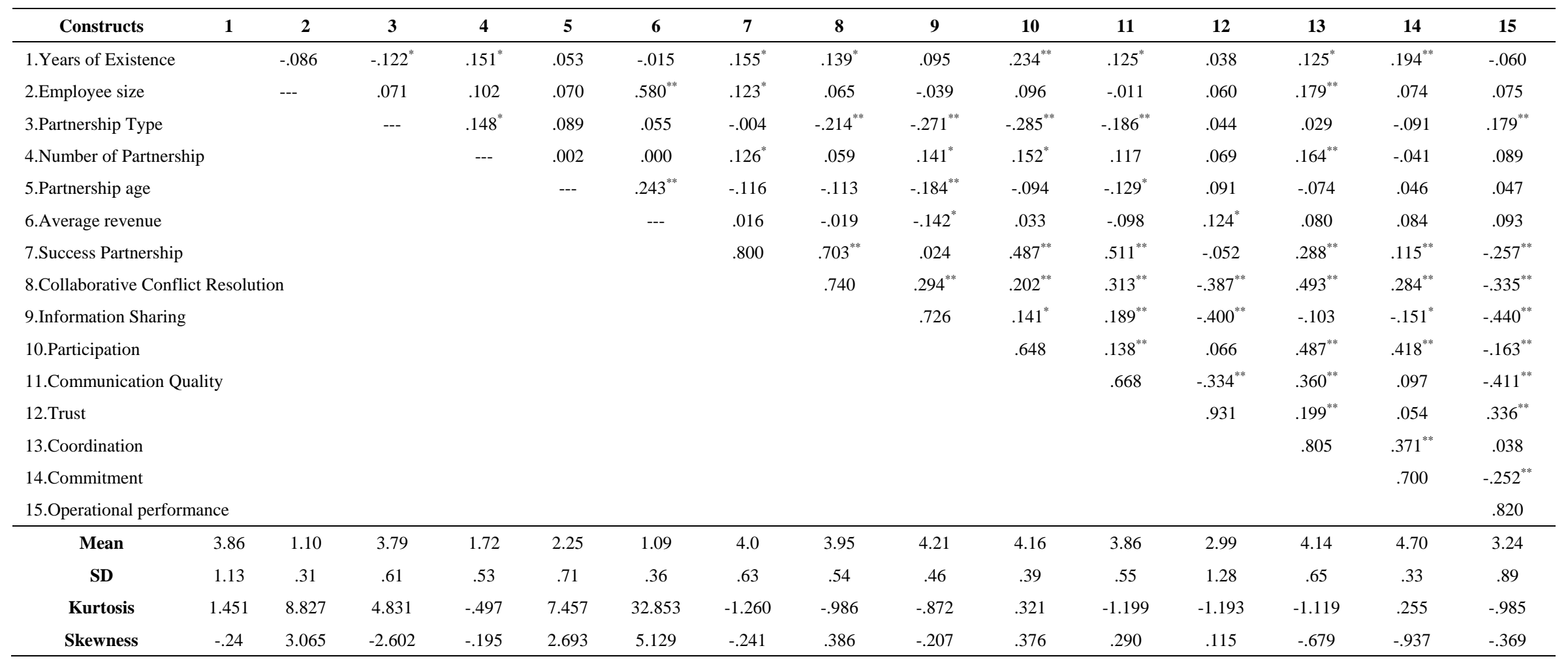

${ }^{*} p<.05,{ }^{* *} p<.01$ (two-tailed test)

Notes: All constructs were measured on a 5-point Likert scale, 1 indicating strongly disagree and 5 indicating strongly agree except for controls. SD=Standard Deviation 
Table 5. Regression analysis of attributes of partnership on the success of partnerships

\begin{tabular}{|c|c|c|c|c|}
\hline \multirow[b]{2}{*}{ Variables } & \multicolumn{4}{|c|}{ Successful Partnership } \\
\hline & $\begin{array}{c}\text { Model A } \\
\text { 乃 (t-values) }\end{array}$ & $\begin{array}{c}\text { Model B } \\
\text { 乃 (t-values) }\end{array}$ & $\begin{array}{c}\text { Model C } \\
\beta \text { (t-values) }\end{array}$ & $\begin{array}{c}\text { Model D } \\
\beta \text { (t-values) }\end{array}$ \\
\hline \multicolumn{5}{|l|}{ Control variables } \\
\hline Years in existence & $.167(2.754)^{* *}$ & $.023(.677)$ & $.036(1.170)$ & $.028(.934)$ \\
\hline Employee size & $.163(2.198)^{*}$ & $.005(.125)$ & $.015(.400)$ & $.017(.453)$ \\
\hline Partnership type & $.031(.512)$ & $.021(.631)$ & $.037(1.171)$ & $.018(.503)$ \\
\hline Number of partners & $.088(1.434)$ & $.032(.939)$ & $.037(1.209)$ & $.038(1.219)$ \\
\hline Partnership age & $-.127(-2.069)^{*}$ & $-.053(-1.552)$ & $-.036(1.175)$ & $-.034(-1.113)$ \\
\hline Average revenue & $-.047(-.626)$ & $-.029(-.696)$ & $-.025(-.671)$ & $-.018(-.482)$ \\
\hline \multicolumn{5}{|l|}{ Independent variable } \\
\hline Commitment & & $.260(7.142)^{* * *}$ & $.160(4.290)^{* * *}$ & $.170(.869)$ \\
\hline Coordination & & $.716(19.147)^{* * * *}$ & $.354(5.970)^{* * *}$ & $-.026(-.101)$ \\
\hline Trust & & $-.206(-6.162)^{* * *}$ & $-.022(-.345)$ & $-.569(-1.270)$ \\
\hline \multicolumn{5}{|l|}{ Moderator variables } \\
\hline Operational performanc & & & $-.235(3.548)^{* *}$ & $-.170(-2.088)^{*}$ \\
\hline \multicolumn{5}{|l|}{ Interaction Effect } \\
\hline \multicolumn{2}{|c|}{ Commitment $\times$ Operational performance } & & & $.085(-1.953)^{+}$ \\
\hline \multicolumn{2}{|c|}{ Coordination $\times$ Operational performance } & & & $.044(-.782)$ \\
\hline Trust $\times$ Operatio & & & & $.090(1.739)^{+}$ \\
\hline $\mathrm{R}^{2}$ & .071 & .725 & .779 & .792 \\
\hline F value & $3.383^{* * *}$ & $76.585^{* * *}$ & $83.546^{* * *}$ & $56.756^{* * *}$ \\
\hline$\Delta_{\mathrm{R}^{2}}$ & & .653 & .055 & .012 \\
\hline Change $F$ value & & $207.192^{* * * *}$ & $32.362^{* * * *}$ & $2.465^{*}$ \\
\hline Degrees of freedom & $6 / 265$ & $9 / 262$ & $11 / 260$ & $17 / 254$ \\
\hline Durbin-Watson & 1.623 & & & \\
\hline
\end{tabular}

${ }^{+} p<.10,{ }^{*} p<.05,{ }^{* *} p<.01,{ }^{* * *} p<.001$. Note: Standardised regression coefficients were reported with t-values for each effect in parentheses.

\section{Analysis and results}

Multicollinearity assumptions were not violated as the results recorded tolerance values of greater than 0.10 and VIF values of less than 10 (Hair et al., [30].

Attributes of partnership: Impact on partnership success

After regressing the attributes of partnership (i.e. commitment, coordination, and trust) on the dependent variable (i.e. successful partnership), Model A in Table 5 shows that the control variable explained $7.1 \%$ of the variance partnership success. After inclusion of the control variable, Model B shows that the explanation increased to $72.5 \%\left(\Delta R^{2}=.653, \Delta F=207.192, p<.000\right)$. In Model $\mathrm{C}$, the moderation variable, operational performance increased $R^{2}$ by $5.5 \%(\Delta F=32.362, p<.000)$.

The introduction of the interaction term in Model D further increased the variance in successful partnership by $1.2 \%\left(R^{2}=.792, \Delta F=2.465, p=.025\right)$. Model B in Table 5 showed that commitment $(\beta=.260, p<.001)$ and coordination $(\beta=.716, p<.001)$ positively impacted successful partnership in support of $\mathrm{H} 1$ and $\mathrm{H} 2$. This underscores the importance of maintaining good commercial relationships in partnerships as it impacts growth and sustainability. Conversely, trust negatively impacted partnership success $(\beta=-.260, p<.001)$, refuting $\mathrm{H} 3$. This is a surprising finding and contradicts Madhok [31] who highlighted the focal role of trust in building partnership relationships.

Model C depicted that operational performance was negatively and significantly related to partnership success $(\beta=-.235, p<.001)$. In Model $\mathrm{D}$, the interaction between coordination and operational performance positively and insignificantly affected successful partnership $(\beta=.044, p$ $=.435)$ not lending support to H8. The interaction between trust and operational performance $(\beta=.090, p=.083)$ positively and significantly related successful partnerships while the product between commitment and operational performance $(\beta=.085, p=.052)$ positively and significantly impacted partnership success lending support to $\mathrm{H} 9$ and $\mathrm{H} 10$ respectively.

Communication behaviour: Impact on partnership success 
In ascertaining the impact of the communication behaviour of partners on the success of partnerships, its dimensions (i.e. communication quality, participation and information sharing) were regressed on the dependent variable. It is evident from Table 6 that the explanation increased in Model B to $58.8 \%\left(\Delta R^{2}=.517, \Delta F=109.451\right.$, $p<.001)$. In Model $\mathrm{C}$, the moderation variable operational performance increased $R^{2}$ by $18.9 \%(\Delta F=110.290, p$ $<.001)$. The introduction of the interaction term in Model $D$ further increased the variance in successful partnership by $3.9 \%\left(R^{2}=.816, \Delta F=9.060, p<.001\right)$. As per Model B, communication quality $(\beta=.712, p<.001)$ and participation $(\beta=.053, p<.001)$ positively impacted on partnership success in support for $\mathrm{H} 4$ and $\mathrm{H} 5$. This suggests that partnerships are likely to succeed when built on quality communication with regards to conferring on issues, planning and making of critical decisions. It further underscores the assertion that poor communication undermines partnership success through increased stress and reduced organisational satisfaction and employee commitment [32].

Conversely, information sharing negatively impacted partnership success $(\beta=-.521, p<.001)$ rejecting H6. In Model $\mathrm{C}$, operational performance positively and significantly impacted partnership success $(\beta=.235, p$ $<.001)$. In Model D, the interaction between participation and operational performance $(\beta=.206, p<.001)$ positively and significantly affected partnership success, thus lending support to H12. The product between communication quality and operational performance $(\beta=.229, p<.001)$ positively and significantly impact partnership success just as the product between information sharing and operational performance $(\beta=.087, p=.059)$ supporting $\mathrm{H} 11$ and $\mathrm{H} 13$ respectively.

Table 6. Regression analysis of communication behaviour on the success of partnerships

\begin{tabular}{|c|c|c|c|c|}
\hline \multirow{3}{*}{ Variables } & \multicolumn{4}{|c|}{ Successful Partnership } \\
\hline & Model A & Model B & Model C & Model D \\
\hline & $\beta$ (t-values) & $\beta$ (t-values) & $\beta$ (t-values) & $\beta$ (t-values) \\
\hline \multicolumn{5}{|l|}{ Control variables } \\
\hline Years in existence & $.167(2.754)^{* *}$ & $.337(1.280)$ & $.051(1.644)$ & $.003(.115)$ \\
\hline Employee size & $.163(2.198)^{*}$ & $.097(1.945)^{+}$ & $.038(1.018)$ & $.054(1.560)$ \\
\hline Partnership type & $.031(.512)$ & $.102(2.344)^{*}$ & $.061(1.893)^{+}$ & $.029(.896)$ \\
\hline Number of partners & $.088(1.434)$ & $.061(1.484)$ & $.039(1.248)$ & $.028(.938)$ \\
\hline Partnership age & $-.127(-2.069)^{*}$ & $-.098(-2.335)^{*}$ & $-.036(-1.138)$ & $-.024(-.808)$ \\
\hline Average revenue & $-.047(-.626)$ & $-.037(-.725)$ & $-.022(-.600)$ & $-.031(-.891)$ \\
\hline \multicolumn{5}{|l|}{ Independent variable } \\
\hline Communication quality & & $.712(11.263)^{* * * *}$ & $.242(4.159)^{* * *}$ & $.703(1.889)^{+}$ \\
\hline Participation & & $.053(6.815)^{* * *}$ & $.183(4.756)^{* * *}$ & $-.430(-2.017)^{*}$ \\
\hline Information sharing & & $-.521(-8.709)^{* * * *}$ & $-.219(-4.352)^{* * *}$ & $.202(.906)$ \\
\hline \multicolumn{5}{|l|}{ Moderator variables } \\
\hline Operational performance & & & $-.235(-5.852)^{* * *}$ & $.001(.009)$ \\
\hline \multicolumn{5}{|l|}{ Interaction Effect } \\
\hline \multicolumn{2}{|c|}{ Communication quality $\times$ Operational performance } & & & $.229(-3.840)^{* * *}$ \\
\hline \multicolumn{2}{|c|}{ Participation $\times$ Operational performance } & & & $.206(5.723)^{* * * *}$ \\
\hline \multicolumn{2}{|c|}{ Information sharing $\times$ Operational performance } & & & $.087(-1.900)^{+}$ \\
\hline $\mathrm{R}^{2}$ & .071 & .588 & .777 & .816 \\
\hline F value & $3.383^{* * *}$ & $41.509^{* * *}$ & $82.348^{* * *}$ & $66.391^{* * *}$ \\
\hline$\Delta \mathrm{R}^{2}$ & & .517 & .189 & .039 \\
\hline Change $\mathrm{F}$ value & & $109.451^{* * *}$ & $110.290^{* * *}$ & $9.060^{* * *}$ \\
\hline Degrees of freedom & $6 / 265$ & $9 / 262$ & $11 / 260$ & $17 / 254$ \\
\hline Durbin-Watson & 1.904 & & & \\
\hline
\end{tabular}

${ }^{+} p<.10,{ }^{*} p<.05,{ }^{* *} p<.01,{ }^{* * *} p<.001$

Note: Standardised regression coefficients were reported with t-values for each effect in parentheses. 
Conflict resolution techniques: Impact on success in partnerships

In Table 7, it is evident that collaborative conflict resolution as per Model $\mathrm{B}$, increased the explanation to $54.1 \%\left(\Delta R^{2}=.470, \Delta F=270.110, p<.001\right)$. In Model C, the moderation variable operational performance increased $R^{2}$ by $22.2 \%(\Delta F=122.691, p<.001)$. The introduction of the interaction term in Model D further increased the variance in successful partnership by $0.4 \%\left(R^{2}=.767, \Delta F\right.$ $=2.074, p=.128$, n.s.). This means collaborative conflict resolution $(\beta=.715, p<.001)$ positively impacted on partnership success, lending support to H7. In Model C, operational performance was negatively and insignificantly impacted partnership success $(\beta=-.072, p=.129)$. In Model D, the interaction between collaborative conflict resolution and operational performance $(\beta=-.047, p=.318$, n.s) negatively and insignificantly affected successful partnership refuting H14.

\section{Summary hypotheses}

Table 8 presents a summary of the hypotheses showing those were supported and otherwise.

Table 7. Regression analysis of conflict resolution on the success of partnerships

\begin{tabular}{|c|c|c|c|c|}
\hline \multirow{3}{*}{ Variables } & \multicolumn{4}{|c|}{ Successful Partnership } \\
\hline & Model A & Model B & Model C & Model D \\
\hline & $\beta$ (t-values) & $\beta$ (t-values) & $\beta$ (t-values) & $\beta$ (t-values) \\
\hline \multicolumn{5}{|l|}{ Control variables } \\
\hline Years in existence & $.167(2.754)^{* *}$ & $.075(1.746)^{+}$ & $.063(2.027)^{*}$ & $.055(1.743)^{+}$ \\
\hline Employee size & $.163(2.198)^{*}$ & $.071(1.345)$ & $.019(.510)$ & $.018(.467)$ \\
\hline Partnership type & $.031(.512)$ & $.170(3.916)^{* * *}$ & $.067(2.101)^{* * *}$ & $.057(1.712)^{+}$ \\
\hline Number of partners & $.088(1.434)$ & $.088(2.037)^{* * *}$ & $.028(.873)$ & $.033(1.028)$ \\
\hline Partnership age & $-.127(-2.069)^{*}$ & $-.057(-1.306)$ & $-.012(-.384)$ & $-.016(-.520)$ \\
\hline Average revenue & $-.047(-.626)$ & $-.006(-.121)$ & $-.014(-.357)$ & $-.011(-.299)$ \\
\hline \multicolumn{5}{|l|}{ Independent variable } \\
\hline Collaborative conflict resolution & & $.715(16.435)^{* * *}$ & $.350(6.215)^{* * *}$ & $-.258(-.814)$ \\
\hline \multicolumn{5}{|l|}{ Moderator variables } \\
\hline Operational performance & & & $-.072(-1.523)$ & $-.001(-.014)$ \\
\hline \multicolumn{5}{|l|}{ Interaction Effect } \\
\hline $\begin{array}{l}\text { Collaborative conflict resolution } \times \\
\text { Operational performance }\end{array}$ & & & & $-.047(-1.000)$ \\
\hline $\mathrm{R}^{2}$ & .071 & .541 & .763 & .767 \\
\hline F value & $3.383^{* *}$ & $44.432^{* * *}$ & $93.683^{* * *}$ & $77.655^{* * *}$ \\
\hline$\Delta \mathrm{R}^{2}$ & & .470 & .222 & .004 \\
\hline Change $\mathrm{F}$ value & & $270.110^{* * *}$ & $122.691^{* * *}$ & 2.074 \\
\hline Degrees of freedom & $6 / 265$ & $7 / 264$ & $9 / 262$ & $11 / 260$ \\
\hline Durbin-Watson & 1.629 & & & \\
\hline
\end{tabular}

${ }^{+} p<.10,{ }^{*} p<.05,{ }^{* *} p<.01,{ }^{* * *} p<.001$

Note: Standardised regression coefficients were reported with t-values for each effect in parentheses. EPM=Economic partnership Motives, PPM=Risk-reduction Partnership Motive 
Table 8. Hypotheses summary

\begin{tabular}{|c|c|c|}
\hline & Description & $\begin{array}{c}\text { Empirical } \\
\text { conclusions }\end{array}$ \\
\hline $\mathrm{H} 1$ & The commitment of partners has a positive relationship with partnership success & Supported \\
\hline $\mathrm{H} 2$ & Coordination has a positive relationship with partnership success & Supported \\
\hline $\mathrm{H} 3$ & Trust among partners has a positive relationship with partnership success & Not supported \\
\hline $\mathrm{H} 4$ & Communication quality has a positive relationship with partnership success & Supported \\
\hline H5 & Participation has a positive relationship with partnership success & Supported \\
\hline H6 & Effective information sharing has a positive relationship with partnership success & Not supported \\
\hline $\mathrm{H} 7$ & $\begin{array}{l}\text { The application of effective conflict resolution techniques has a positive relationship with partnership } \\
\text { success }\end{array}$ & Supported \\
\hline $\mathrm{H} 8$ & $\begin{array}{l}\text { The positive relationship between commitment and partnership success will be stronger when the } \\
\text { operational performance of the partnership is high than low }\end{array}$ & Supported \\
\hline H9 & $\begin{array}{l}\text { The positive relationship between coordination and partnership success will be stronger when the } \\
\text { operational performance of the partnership is high than low }\end{array}$ & Not supported \\
\hline $\mathrm{H} 10$ & $\begin{array}{l}\text { The positive relationship between trust among partners and partnership success will be stronger when } \\
\text { the operational performance of the partnership is high than low }\end{array}$ & Supported \\
\hline H11 & $\begin{array}{l}\text { The positive relationship between communication quality among partners and partnership success will } \\
\text { be stronger when the operational performance of the partnership is high than low }\end{array}$ & Supported \\
\hline H12 & $\begin{array}{l}\text { The positive relationship between partner participation and partnership success will be stronger when } \\
\text { the operational performance of the partnership is high than low }\end{array}$ & Supported \\
\hline H13 & $\begin{array}{l}\text { The positive relationship between effective information sharing among partners and partnership success } \\
\text { will be stronger when the operational performance of the partnership is high than low }\end{array}$ & Supported \\
\hline H14 & $\begin{array}{l}\text { The positive relationship between the application of effective conflict resolution among partners and } \\
\text { partnership success will be stronger when the operational performance of the partnership is high than } \\
\text { low }\end{array}$ & Not supported \\
\hline
\end{tabular}

\section{Discussion and Implications}

\section{Summary of findings}

This study was designed to analyze the critical success factors in Ghanaian professional services firms using a sample size of 276 participants. Analyses of the data obtained after cleaning, coded and entered into the SPSS software was done in three phases. The following are the summaries of the findings:

First, on the demographic characteristics of respondents, the study revealed that majority of the respondents was males. Age of respondents varied between below 20 years and 41 years and above. However, the majority of the respondents indicated they were 41 years and above. Concerning work position, the majority of the respondents indicated they were managers. In terms of work experience, the majority of the respondents indicated they had served for more than 10 years. The final demographic variable measured was educational status, more than half of the respondents revealed they had attained a bachelor's degree.

On the demographic characteristics of the organisations, the majority of the respondents indicated they had a workforce of fewer than 20 employees. Also, the majority of the respondents indicated their company had been in existence between $11-15$ years. The next variable examined was partnership type, the majority of the respondents revealed that their partnership type was general practice and had at least 2 partners. Majority of the respondents revealed their partnership was 2 years old. The final demographic variable examined under the background characteristics of the business was average revenue. Majority of the respondents indicated they firms earned less than $\mathrm{GH} \phi 5$ million annually.

The second phase of the analysis comprised of an EFA test, internal consistency and reliability test and correlation between the variables. The EFA was adopted to test the factorial validity of the scales. Findings from the EFA showed that all the variables successfully loaded under each scale with factor loading values of 0.5 and above. On internal consistency and reliability test, the Cronbach Alpha values obtained for the various constructs were greater than ' 0.50 ' the minimum requirement generally accepted. Analyses on the correlation between the various variables revealed that none of the variables were highly correlated.

The final phase of the analysis was estimating a hierarchical regression model with the success of partnership as the dependent variable. Upon estimating the regression model, commitment, coordination, communication quality, participation, and effective conflict resolution were the significant determinants of success of the partnership.

\section{Discussion}

Impact of partnership attributes

A positive relationship was hypothesised as existing between the three dimensions of partnership attributes (i.e. commitment, coordination, and trust) and partnership success. Whereas the results supported the proposed relationship for commitment $(\mathrm{H} 1)$ and coordination $(\mathrm{H} 2)$, a 
negative impact was reported for trust (H3). Indeed, past studies [33] assert that commitment among partners is crucial to the growth and survival of the partnership. Committed partners tend to act in ways that do not undermine the achievement of the collective goals of partners; thus, promoting the effectiveness of the partnership. Also, commitment helps in the quick adaptation of partners to changes within their business environment as parties place their respective resources and time to make things work out.

In the absence of coordination, parties to a partnership are less likely to make any meaningful headway towards achieving their collective goals. Similar to Mohr and Spekman [5], the current study that coordination promotes harmony and satisfaction among partners and eventually results in improved productivity. Coordination acts as an information sharing and joint action platform for members of a partnership for the execution of tasks connected to the achievement of their common goals. In a surprising contraction to the work of Monczka et. al., [13], a negative relationship was found between the trust dimension of partnership attributes and partnership success; suggesting that PSFs must focus on the first two dimensions but does not mean they should ignore the trust component.

\section{Impact of communication behaviour}

It emerged that communication quality and participation are the dimensions of communication behaviour that had a positive and significant impact on partnership success. Conversely, information sharing had a negative impact. High quality of communication enables the seamless interaction and exchange of information among stakeholders to a partnership. This breeds partnership success given that communication underpins the workable coordinating mechanisms necessary for exchange activities and building strong partnership relationships. Consequently, PSFs need to build the communication competence of their staff to foster effective planning of activities aimed at helping partnership stakeholders achieve their common goals. The findings on communication quality for this study corroborate that of others who that communication is critical to the success of partnership among firms.

In the same vein, the findings confirmed that participation is a key antecedent of partnership success as it motivates partners to actively engage themselves in activities designed to enable the achievement of common partnership goals. Participation helps strengthen the cords of the relationship among partners through joint planning and consultations on critical issues. It is meanwhile contradictory that information sharing surprisingly was not a significant predictor of partnership success.

Impact of collaborative conflict resolution

The results confirmed the collaborative conflict resolution has a positive impact on partnership success.
Conflicts constitute a part of many partnerships therefore PSFs that build their capacity in deploying diverse strategies to address them are more likely to succeed. The poor handling of conflicts will naturally undermine the growth and survival of partnerships.

\section{The moderating role of operational performance}

The results demonstrated that operational performance positively moderated the relationship between commitment and trust as attributes of partnership and partnership success. It, however, failed to moderate the relationship between coordination and partnership success. Operational performances refer to the internal, unobservable force that generates a person's efforts, drive, and persistence toward the achievement of a pre-determined worthwhile goal. However, operational performances can have adverse consequences on the success of partnerships if individual partners prioritize their interest ahead of that of the partnership. Although commitment among partners may be a key prerequisite for the success of partnerships, selfish motives among partners will undermine the growth and eventual survival of the partnership relationship. The interaction between trust and operational performances was positive and significantly related to the success of partnerships. When partners trust each other there is a great chance that their partnership would succeed and survive. Trust combined with positive operational performances of partners is the key in achieving the utmost productivity and longevity of the partnership. The results thus correspond with a study by Brouthers et.al. [27], which stated that firms merge due to several reasons including economic and personal reasons.

The interaction coefficient between communication quality and operational performances was negative implying a decrease in the success of the partnership. Operational performances have a consequential impact on the success of partnerships. If the partner's operational performances are negative, their actions would most likely harm the success of the partnership although there may be quality communication among them. Also, the interaction between partner participation and operational performances was positive. The magnitude of the positive relationship implies an increase or rise in the success of the partnership. As aforementioned, negative operational performances of partners have a detrimental impact on the success of the partnership, however, positive motives of partners have a successful impact on partnership success. Hence, positive motives and effective partner participation would lead to the success of the partnership.

The regression results revealed a positive and significant interaction between collaborative conflict resolution of partners and the operational performance. When operational performance is in the interest of the partnership, the success of the partnership is assured. Partnership even becomes more successful if conflicts are resolved anytime, they arise. The above results correspond with a study by 
Brouthers et.al. [27], which stated that firms merge due to many reasons including economic and personal reasons.

\section{Conclusion and implications}

Commitment emerged from this study as a critical component of achieving success in partnerships. Also, skills and expertise are not enough for partnership success as these resources offered by the individual partners need to be effectively coordinated. Coordination is important in ensuring that the activities of partners are all streamlined into a seamless flow to aid operations. This is important so that, the partners do not operate in a separate and disjointed manner. Most partnerships fail on the back of limited information flow hence, the right kind of information must be encouraged among members. This needs to be done with the maintenance of the highest level of communication quality since it also had a significant impact on partnership success.

When a partnership is formed, it is expected that each partner performs certain functions that complement those of the other partners. Hence, the shirking of responsibilities undermines the success of the partnership relationship. Participation is considered important and so also is the need to periodically discuss the roles and responsibilities of partners so that each partner participates as expected. This view supports the point that effective communication sharing among partners facilitates participation.

From a practice perspective, PSFs need to view partnerships as a strategic option to break the constraints imposed on them by their peculiar regulatory environment and aid the internationalisation of their operations. With many SMEs failing within the first 3 years of their existence and the increased competition PSFs face from foreign service provides, effective partnerships coupled with commitment and workable communication guidelines is of utmost importance for their survival. Communication must be used to improve trust among members of the partnership to strengthen the relationship bond and promote its sustainability. Also, it is recommended that efforts be made to create an integrated coordinated system that fosters accountability among partners. A culture of candour is also needed among members of a partnership for rich divergent views to thrive. This is important when one considers the fact that divergent views may lead to better solutions to give the partnership a competitive edge.

The implication for future research is that this paper recommends replication of the current study in knowledge-intensive sectors of the economy of other emerging markets using larger sample sizes to further enhance the generalizability of the present results. Also, future studies can focus on other determinants such as micro and macroeconomic factors that are most likely to influence the success of partnerships. Using moderator variables such as operational performance could equally be useful in future studies to investigate the relationships proposed in the conceptual model of the current study.

\section{Declaration of Conflicting Interests}

The author declared no potential conflicts of interest with respect to the research, authorship and/or publication of this article.

\section{Funding}

The author received no financial support for the research, authorship and/or publication of this article.

\section{REFERENCES}

[1] Thiel, M. (2019), "Examining Partnership Success and Failure", SDG17: Partnerships for the Goals: Strengthening Implementation Through Global Cooperation (Concise Guides to the United Nations Sustainable Development Goals), Emerald Publishing Limited, pp. 43-50.

[2] Casey, M. (2008). Partnership-success factors of inter-organizational relationships. Journal of nursing management, 16(1), 72-83.

[3] Zineldin, M., \& Vasicheva, V. (2016). Marriage versus strategic alliance: soft and hard dissatisfaction and failure factors. International Journal of Strategic Business Alliances, 5(1), 22-33.

[4] Tuten, T. L., \& Urban, D. J. (2001). An expanded model of business-to-business partnership formation and success. Industrial marketing management, 30(2), 149-164.

[5] Mohr, J., \& Spekman, R. (1994). Characteristics of partnership success: partnership attributes, communication behaviour, and conflict resolution techniques. Strategic management journal, 15(2), 135-152.

[6] Gardner, H. K., Anand, N., \& Morris, T. (2008). Chartering new territory: Diversification, legitimacy, and practice area creation in professional service firms. Journal of Organizational Behavior, 29(8), 1101-1121.

[7] Brown, J. L., Cooper, D. J., Greenwood, R., \& Hinings, C. R. (1996). Strategic alliances within a big-six accounting firm: A case study. International Studies of Management \& Organization, 26(2), 59-79.

[8] Blau, P. M., \& Scott, W. R. (1962). Formal Organizations: A Comparative Approach (San Francisco: Chandler). BlauFormal Organizations: A Comparative Approach1962.

[9] Mohr, J. J., Fisher, R. J., \& Nevin, J. R. (1996). Collaborative communication in interfirm relationships: moderating effects of integration and control. Journal of Marketing, 60(3), 103-115.

[10] Kwon, Y. C. (2008). Antecedents and consequences of international joint venture partnerships: A social exchange perspective. International Business Review, 17(5), 559-573.

[11] Lee, S., \& Lim, G. G. (2003). The impact of partnership attributes on EDI implementation success. Information \& Management, 41(2), 135-148. 
[12] Atouba, Y. C., \& Shumate, M. D. (2019). Meeting the Challenge of Effectiveness in Nonprofit Partnerships: Examining the Roles of Partner Selection, Trust, and Communication. VOLUNTAS: International Journal of Voluntary and Nonprofit Organizations, 31, 301-315.

[13] Monczka, R. M., Petersen, K. J., Handfield, R. B., \& Ragatz, G. L. (1998). Success factors in strategic supplier alliances: the buying company perspective. Decision Sciences, 29(3), 553-577.

[14] Altinay, L., Brookes, M., Madanoglu, M., \& Aktas, G. (2014). Franchisees' trust in and satisfaction with franchise partnerships. Journal of Business Research, 67(5), 722-728.

[15] Du, T. C., Lai, V. S., Cheung, W., \& Cui, X. (2012). Willingness to share information in a supply chain: A partnership-data-process perspective. Information \& Management, 49(2), 89-98.

[16] Sikhwari, T. M. (2016). The influence of supplier information sharing and information quality on strategic partnerships and internal lean practices among SME's in South Africa. Business \& Social Sciences Journal, 1(2), $68-85$.

[17] Kim, M., \& Chai, S. (2017). The impact of supplier innovativeness, information sharing and strategic sourcing on improving supply chain agility: Global supply chain perspective. International Journal of Production Economics, $187,42-52$

[18] Wu, M., Weng, Y. and Huang, I. (2012), "A study of supply chain partnerships based on the commitment - trust theory", Asia Pacific Journal of Marketing and Logistics, 24(4), 690-707.

[19] Butt, A.S. (2019), "Guanxi and intra-organizational conflicts: evidence from Chinese logistics industry", Management Research Review, 42(4), 495-505.

[20] Tsasis, P. (2009). The social processes of inter-organizational collaboration and conflict in nonprofit organizations. Nonprofit management and leadership, 20(1), 5-21.

[21] Bryman, A. (2016). Social research methods. Oxford University Press: Oxford, United Kingdom.

[22] Caesar, D. L. (2016). The global shortage of ship officers: an investigation of the complexity of retention issues among Australian seafarers (Doctoral dissertation, University of Tasmania), Launceston, Australia.

[23] Rusbult, C. E., Martz, J. M., \& Agnew, C. R. (1998). The investment model scale: Measuring commitment level, satisfaction level, quality of alternatives, and investment size. Personal relationships, 5(4), 357-387.

[24] Jones, J., \& Barry, M. M. (2011). Developing a scale to measure trust in health promotion partnerships. Health promotion international, 26(4), 484-491.

[25] Ann Marie Thomson, James L. Perry, Theodore K. Miller, Conceptualizing and Measuring Collaboration, Journal of Public Administration Research and Theory, Volume 19, Issue 1, January 2009, Pages 23-56, https://doi.org/10.1093 /jopart/mum036

[26] de Waal, A., Goedegebuure, R. and Hinfelaar, E. (2015), "Developing a scale for measuring high performance partnerships", Journal of Strategy and Management, Vol. 8 No. 1, pp. 87-108.https://doi.org/10.1108/JSMA-07-2014-0 065

[27] Brouthers, K.D., van Hastenburg, P. and van den Ven, J. (1998) If Most Mergers Fail Why Are They So Popular? Long Range Planning, 31, 347-353.http://dx.doi.org/10.101 6/S0024-6301(98)80002-2

[28] Gaumer Erickson, A. S., Soukup, J. H., Noonon, P. M., \& McGurn, L. (2016). Self- Efficacy Questionnaire. Lawrence, KS: University of Kansas, Center for Research on Learning. Retrieved from http://researchcollaboration.org/uploads/Sel f-EfficacyQuestionnaire.pdf

[29] Cronbach, L. J. (1951). Coefficient alpha and the internal structure of tests. Psychometrika, 16(3), 297-334.

[30] Hair, J. F., Black, W. C., Babin, B. J., Anderson, R. E., \& Tatham, R. L. (1998). Multivariate data analysis. Upper Saddle River, New Jersy: Prentice Hall.

[31] Madhok, A. (1995) Opportunism and Trust in Joint Venture Relationships: An Exploratory Study and a Model. Scandinavian Journal of Management, 11, 57-74. http://dx.doi.org/10.1016/0956-5221(94)00029-H

[32] Zhang, H. and Agarwal, N.C. (2009) The Mediating Roles of Organizational Justice on the Relationships between HR Practices and Workplace Outcomes: An Investigation in China. International Journal of Human Resource Management, 20, 676-693. http://dx.doi.org/10.1080/09585 190802707482

[33] Tellefsen, T., \& Thomas, G. P. (2005). The antecedents and consequences of organizational and personal commitment in business service relationships. Industrial Marketing Management, 34(1), 23-37. 